\title{
Serine/Threonine-Protein Kinase MARK2
}

National Cancer Institute

\section{Source}

National Cancer Institute. Serine/Threonine-Protein Kinase MARK2. NCI Thesaurus. Code C126472.

Serine/threonine-protein kinase MARK2 (788 aa, $~ 88 \mathrm{kDa}$ ) is encoded by the human MARK2 gene. This protein plays a role in both microtubule dynamics and serine/threonine phosphorylation. 